\title{
1. Introduction: democracy and exchange
}

Democracy is the sovereignty of the ruled. Profoundly out of sympathy with the traditional aristocracy of birth or the new plutocracy that wants to buy its way into control, it is the commitment that the people alone can be the principal, that self-rule alone can put oughtness into authority.

Exchange is the quid pro quo. It is the self-interested negotiation of equivalence and the factored-down freedom of choice. It is the market mechanism that makes the contract between the buyer and the seller the sole test and measure of value.

Democracy and exchange are the two pillars of the liberal order. Each is an embodiment of individualism and equality. Each stands for tolerance, acceptance and pluralism. Democracy settles disputes through consultation and participation on the basis of one person, one vote. Exchange mediates and adjudicates through matching the revealed preference to the reservation price. Both democracy and exchange are about conflict resolution and collective choice. Each is a civilised way of saying that consent is superior to banditry, compromise to command.

The subject of this book is the politics and the economics of making ordinary people feel tolerably happy with the outcomes that define their lives. More specifically, its subject is how different thinkers have perceived the relationship between the State and the market in the real-world mix where both pillars are essential if the liberal order is to hold. Perceptions are not facts, eternal truths that must be swallowed whole. Rather they are alternatives, different windows on a world which reveals all too little about what it is and what it is becoming. This book concentrates on the insights of Schumpeter, Galbraith, T.H. Marshall, Titmuss and Adam Smith to show that the theories of political economy can be as stimulating as the subject-matter of political economy will always be an invitation to debate.

\subsection{DEMOCRACY}

Democracy means that the demos is in control: 'In democracies the people are sovereign, in oligarchies the few' (Aristotle, 1981: 187). In democracies the multitude has the last word, the final say, 'even over the laws': 
'Whatever the majority decides is final and constitutes justice' (ibid.: 279, 362).

Democracy cannot be compared to a colony that is ruled from abroad: 'A government is democratic to the extent that it is responsible to its subjects' (Plamenatz, 1973: 110). Democracy, whether in a nation, a locality, a factory or a union, is government made legitimate by the consent of the governed. Without the consent of the followers there can be good governance or bad governance but not the power of the people over itself.

Locke, reasoning from the world of things that the empiricist can see and touch, reached the conclusion that 'all men by nature are equal' (Locke, 1689: 141). Tawney, starting from the revelation that God the Father had created all humankind in his image, said that 'the necessary corollary ... of the Christian conception of man is a strong sense of equality' (Tawney, 1937: 182). Equality to Locke and Tawney was a non-negotiable constant. It is a bedrock absolute upon which political democrats have built in order to construct their principled defence of inclusiveness and involvement.

Democracy, direct or representative, presupposes universal adult suffrage. While children and madmen are logically excluded since they lack a rational understanding of the benefits and costs, no other citizens can equitably be denied the franchise on the grounds of politically non-relevant characteristics such as race, age, income, wealth, gender, tribe, religion or level of education. A man's a man for a' that. A woman is no different. Democracy is plebescitarianism. Democracy is equal rights.

Democracy is the process 'by which ordinary citizens exert a relatively high degree of control over leaders' (Dahl, 1956: 3). It is the imperative that each is to count as one, no one for more nor less. It is, as Aristotle explains it, an open and free order in which no individual has greater voting power than any other, in which every citizen has the right to hold office and rise to the top: 'A basic principle of the democratic constitution is liberty. ... "Ruling and being ruled in turn" is one element in liberty, and the democratic idea of justice is in fact numerical equality, not equality based on merit' (Aristotle, 1981: 362). Democracy is dependable accountability to the popular base. Democracy is participation and power sharing, not dominance and the tyranny of autocracy. Democracy is the equal opportunity to mould and shape.

Locke argued strongly that 'the appointment and consent of the people' was the sole source of legitimacy but that the primary function of the polity was peace: 'The end of law is not to abolish or restrain, but to preserve and enlarge freedom ... Where there is no law, there is no freedom' (Locke, 1689: 230, 142). The supporters of universal suffrage believe that the Lockean means of consent cannot be at variance with the Lockean end of social havid Re1smyn The 9781845426828 
opponents of universal suffrage are less confident. They say that innate equality need not point to an equal vote. They deny that an equal vote will necessarily ensure that personal security that attracted men out of the Lockean natural state. Ireton, in the Army debates at Putney, spoke for such sceptics when he made clear that he was no radical Leveller who would give a man a vote merely because he was born in England. Citizenship, Ireton said, carries with it no ipso facto right to deliberate upon the laws or to share in the choice of the representatives. Affiliation is necessary. It is not, however, sufficient.

Ireton took the view that no person should have a right to influence common affairs 'that hath not a permanent fixed interest in this Kingdom': 'All the main thing that I speak for, is because I would have an eye to property' (cited in Woodhouse, 1938: 54, 57). Ireton rejected the idea that a man cannot be bound by a law to which he has not given his consent: a resident foreigner is expected to conform to the local statutes or leave. A citizen without permanent property is, like the foreigner, a tourist without a stake. Since he has not made an investment in the nation, there is no reason for him to be given a vote.

Speaking against Ireton at Putney in the Commonwealth interregnum that had just put a hereditary monarch to death was Colonel Rainborough. Rainborough made a case for equality through democracy on the basis of his conviction, expressed as a Civil War soldier who was risking his life for the group, that person and birthright were every bit as valuable a property as was the possession of an estate: 'Really I think that the poorest he that is in England hath a life to live, as the richest he; and therefore truly ... I think it is clear, that every man that is to live under a government ought first by his own consent to put himself under that government; and I do think that the poorest man in England is not at all bound in a strict sense to that government that he hath not had a voice to put himself under' (ibid.: 53).

No hewer of wood, no drawer of water, should be excluded from the assentseeking process. To be so excluded would be to become the slave or instrument of another. That, Colonel Rainborough concluded, would have no moral basis at all: 'I do not find anything in the Law of God, that a Lord shall choose twenty burgesses, and a gentleman but two, or a poor man shall choose none: I find no such thing in the Law of Nature, nor in the Law of Nations' (ibid.: $56)$.

Rainborough may have spoken too soon. Equal citizens may or may not be equal in their stake. What is much less likely is that they will be equal in their database and their critical apprehension. Nature in that sense plays the unkind trick of making the birthright equals functionally unequal. Intelligence and capacity are a pyramid-shaped distribution. Madmen and children are all around. 
Edmund Burke was the frightened Jeremiah who inveighed against the 'rabble' and the 'mob' at the time when the French Revolution was extending the right to vote even to the hairdressers and the tallow-chandlers: 'The State suffers oppression, if such as they, either individually or collectively, are permitted to rule. In this you think you are combating prejudice, but you are at war with nature' (Burke, 1790: 138). Adam Smith had no greater faith in the common sense of the common people, 'so jealous of their liberty' but 'never rightly understanding wherein it consists' (Smith, 1776: I, 157). Debased into 'drowsy stupidity' (Smith, 1776: II, 303) by the mind-numbing division of labour, the worker is the victim of nurture rather than nature but a fallen creature nonetheless: 'Of the great and extensive interests of his country he is altogether incapable of judging' (ibid.: II, 303). Democracy presupposes the responsible exercise of rights and functions. It falls into disrepute once the hairdressers and the tallow-chandlers make it an excuse for legalised looting and the settling of scores.

Marx, like Adam Smith, believed that, in Tocqueville's memorable phrase, 'the art advances, the artisan recedes' (Tocqueville, 1840: II, 159). The spiritual decline is the inevitable consequence of productivity-enhancing processes that leave the spindled operative 'mentally and physically dehumanized' (Marx, 1844a: 121). Mutilated into a 'fragment of a man', shrunken into 'an appendage of a machine' (Marx, 1867: 645), the worker is not in a position to give his informed consent for the simple reason that there is no considered opinion that he can call his own.

The Marxian proletariat is 'dehumanisation which is conscious of its dehumanisation, and therefore self-abolishing' (Marx and Engels, 1845: 36). It is 'poverty artificially produced', a nothingness in its own eyes which 'can only redeem itself by a total redemption of humanity' (Marx, 1844b: 190). At least it has a clear enough insight into the causal link between private capital and its own 'misery, agony of toil, slavery, ignorance, brutality, mental degradation' (Marx, 1867: 645) to want to force through a revolution against the classdriven order that has for too long been the negation of its gravediggers: 'The emancipation of society from private property, etc., from servitude, is expressed in the political form of the emancipation of the workers' (Marx, 1844a: 118). The Marxian proletariat, 'annihilated in estrangement', wants to execute 'the sentence that private property pronounces on itself', to 'abolish itself and thereby its opposite, private property' (Marx and Engels, 1845: 36). The Leninist proletariat does not want even that: 'Slumbering, apathetic, bound by routine, inert, and dormant' (Lenin, 1920: 73), the Leninist masses must forever dwell on their privatisation shares and their summer holidays in the absence of a communist vanguard that knows it is futile to put real faith in the shallow consciousness of the man in the street. 
Burke and Smith, Marx and Lenin, all inferred that egalitarian democracy could be frustrated by a stunted individualism that had nothing much to say. Tocqueville, predicting that the modern era will be the era of cultural conformity and regression to the mean, was able to trace back the erosion of selfconfident independence to the tyranny of all over each that makes the democratic masses too frightened, too 'other-directed' (Riesman, 1950: 21), to want to stand out from the crowd: 'In the ages of equality, it may be foreseen that faith in public opinion will become for them a species of religion, and the majority its ministering prophet' (Tocqueville, 1840: II, 11). Democracy and individualism are supposed to allow each citizen to give voice to his convictions. Coercion by consensus causes each shaky ego to question whether the face in the crowd has any right to convictions at all: 'As men grow more alike, each man feels himself weaker in regard to all the rest; as he discerns nothing by which he is considerably raised above them or distinguished from them, he mistrusts himself as soon as they assail him' (Tocqueville, 1840: II, 261).

Individualism threatens individuation. The Americans are the proof: 'It seems at first sight as if all the minds of the Americans were formed upon one model, so accurately do they follow the same route' (Tocqueville, 1835: I, 267). If the division of labour did not undermine individual differentiation, Tocqueville believed, then equality and public opinion would do so. The result was likely to be a mass-produced society in which the will of the people would be the will of Mill's 'collective mediocrity'. Mill writes that 'at present individuals are lost in the crowd' (Mill, 1859: 131). Where the equal individual has disappeared into the group, political democracy cannot realistically be a meaningful forum for the intrinsic self.

Aristotle said that some people are too 'slave-like' to be able to think creatively, some so savage that they are 'hardly any better than wild animals' (Aristotle, 1981: 203, 204). Plato's hostility towards the canaille had evoked undoubted resonances in the Lyceum that was built upon his Academy.

Reservations about the downside of equality have caused nervous democrats to recommend selective discrimination in favour of the hoi mesoi, selective safeguards against the hoi polloi. Their proposals have embraced a literacy test, double votes for graduates, university-specific Members of Parliament, an electoral college, a presidential veto with the power to reverse a rogue result. Education - 'We must educate our masters' - and, indeed, occupational upgrading have the same effect in the sense that they strengthen the middle-class electorate that knows its camembert from its brie, its Richmond from its Putney. When all is said and done, however, democracy is individualism and the acceptance of equality. What the hoi polloi want, the hoi polloi must have. That is what give and take and respect for persons are all about: 'Democracy is not only or even primarily a means through which different 
groups can attain their ends or seek the good society; it is the good society itself' (Lipset, 1960: 403).

A strict moralist like Lipset believes that democracy is an absolute and not an economic tradable. A cautious instrumentalist like Dahl takes the less uncompromising position that rectitude has its costs as well as its benefits and that, in the marketplace for institutions, 'most of us are marginalists': 'Political equality and popular sovereignty are not absolute goals; we must ask ourselves how much leisure, privacy, consensus, stability, income, security, progress, status, and probably many other goals we are prepared to forego for an additional increment of political equality' (Dahl, 1956: 51). Democracy in some cases will be the most cost-effective tool for the job. In other cases a different mechanism will deliver a more satisfactory result. There is, Dahl argues, no a priori reason to think that democracy will always score best on the pragmatic test of performance. Nor is it in keeping with common sense to treat democracy as an inviolable objective that must always come first. Dictatorship without crime and government unions that never go on strike have their selling points as well.

The discipline of the barracks succeeds where front-line polling booths would fail. So transparent is the up-and-doing image of the benevolent despot who gets things done that it is easy, as with the invisible hand of the economic market, to overlook the frequency with which decentralisation and not concentration will maximise the quality of collective choice. Aristotle was one of the first not to mistake the Great Man for the substance.

Democracy, Aristotle says, produces good results since large numbers cancel out self-regarding partialities: 'A crowd is, on numerous occasions, actually a better judge than one man, whoever he may be' (Aristotle, 1981: 222). Many heads will often be better than one. Even a philosopher-ruler in the sense of Plato will fall victim to intellectual constraints and information overload. The 'superiority of the many over the sound few' lies precisely in the fact that the few lack the knowledge and the perspicuity that a large pool is able to concentrate: 'An individual ruler, if he has been well educated by law, gives good decisions; but he has only one pair of eyes and ears, one pair of feet and hands. . . . It would be a paradox if he had better vision in judgement and action than many men with many pairs' (ibid.: 203, 228).

Sectional clashes are defused where conflicting interests are given a say. Consensus is reinforced where 'elections to office by all from among all' (ibid.: 363) net out the divisive irritants of clan, wealth, religion or locality. The 'rule of all over each and of each by turns over all' (ibid.: 363) rotates the chairmen and keeps coercion in tune with its roots. Democracy gives the people what they want. They buy the product because the product delivers the voice that they desire.

Specialisation is a problem: each citizen sees only a part of the bundle $e_{\text {David Reisman }}$ i $_{81845426828}$ 
Democracy is the solution: the many together have a better overview than any single expert can in isolation command. The whole in that sense is logically superior to the sum of the parts: 'It is possible that the many, no one of whom taken singly is a sound man, may yet, taken all together, be better than the few, not individually but collectively, in the same way that a feast to which all contribute is better than one supplied at one's expense' (ibid.: 202). Galbraith, writing of the technostructure, praises the committee for its ability as a democracy to synthesise a heterogeneity of perspectives: 'Decision in the modern business enterprise is the product not of individuals but of groups' (Galbraith, 1967: 79). Aristotle, pioneering the insight that diverse beings can 'become one in regard to character and intelligence', makes the same point, that there is 'virtue and practical wisdom' (Aristotle, 1981: 202-3) in the magnifying lens of the whole.

Aristotle was able in the circumstances to extend a cautious welcome to the kind of society in which Rainborough's 'inferior persons' have 'sovereign control' - and Ireton's 'respectable sort' (ibid.: 205) do not. The masses at least are too numerous to be in a position to turn the State into a family firm: 'The many are less easily corrupted. As a larger amount of water is less easily polluted, so the multitude is less easily corrupted than the few' (ibid.: 222). Plato's wise oligarchs were wise enough to recognise where their fortune lay. History is the record of their avarice: 'The good men did not remain good: they began to make money out of that which was the common property of all' (ibid.: 223). Democracy at least provides a decision making structure within which the decision makers will be less likely to bend the law.

\subsection{EXCHANGE}

Life in the State-less state of nature was not sociable and harmonious. It was 'solitary, poor, nasty, brutish, and short' (Hobbes, 1651: 82). Anarchy was red in tooth and claw. Thus it is that rational man may be presumed to have signed away a small part of his liberty to the State in order to preserve the greater part of his freedom for himself: 'The end of civil society' is 'to avoid, and remedy those inconveniences of the state of nature, which necessarily follow from every man's being judge in his own case' (Locke, 1689: 159). The political order is a mutual-defence compact according to which the signatories agree to be bound by the enforcers because the protection-less depredation of the bellum omnium contra omnes is too dreadful a dystopia to bear: 'This is that, and that only, which did, or could give beginning to any lawful government in the world' (ibid.: 165). The restrictions are a bind. Absolute licence, however, is many times worse. The quid pro quo is the rational response.

Man, Locke argues, is unreservedly born free. He is born with 'a title to 
perfect freedom, and an uncontrolled enjoyment of all the rights and privileges of the law of nature, equally with any other man, or number of men' (ibid.: 157). The fact that not one man but every man is born with the same unquestionable title to 'his life, liberty and estate' (ibid.: 157) is precisely the reason why coercion is unacceptable save where it is coercion that is legitimated by consent: 'Men being . . . by nature, all free, equal and independent, no one can be put out of his estate, and subjected to the political power of another, without his own consent. The only way whereby anyone divests himself of his natural liberty, and puts on the bonds of civil society is by agreeing with other men to join and unite into a community' (ibid.: 163).

Consent may be expressed and formal (the case of the ab initio congress that drafts a greenfield constitution) or it may be tacit and implied (as where an existing code is passively perpetuated by a citizenry that is satisfied enough). Newly negotiated or merely pass-through, what is crucial is the compact that is the sine qua non. Free men sign the social contract because they are prepared to live under the laws that are validated by the majority: 'And thus the community may be said in this respect to be always the supreme power' (ibid.: 191). The power of the politicians is 'derived from the people by a positive voluntary grant and institution' (ibid.: 188). That power is not discretionary, arbitrary and in perpetuo but rather fiduciary, delegated and pro tempore. Pirates and robbers should not think that they can act as a Leviathan because of a mandate that in truth is only theirs on loan.

Free men hire a governor because they believe contracted constraint to be the optimal means to their consensual end. Their obedience is, however, forfeit when their servant, promising to protect them from 'polecats, or foxes', himself exercises unlimited prerogative and turns into an uncaged lion instead: 'In all states and conditions the true remedy of force without authority, is to oppose force to it' (ibid.: 161, 194). Such a revolt is absolutely in line with the spirit of the contract: 'It can never be supposed to be the will of the society, that the legislative should have a power to destroy that, which everyone designs to secure, by entering into society' (ibid.: 227). Stakeholders hire a governor because they are dissatisfied with the natural state. They feel deceived and cheated if a Hobbesian absolutist thereupon enters into a state of nature with them.

Salus populi suprema lex: 'the end of government' is 'the good of the community' (ibid.: 199). Vox populi, vox dei: the hired representative is only the conduit for 'the public will of the society' (ibid.: 192). The model is consumer sovereignty. The political exchange is market economics from start to finish.

Liberal democracy, historically speaking, evolved from an abstract ideal into an institutional expectation in the capitalist era that was ushered in by the Industrial, the French and the American Revolutions: 'Liberal-democracy and 
capitalism go together. Liberal-democracy is found only in countries whose economic system is wholly or predominantly that of capitalist enterprise' (Macpherson, 1966: 4). Political democracy and market exchange, historically speaking, have been closely correlated. To find one leads to the expectation that the other cannot be far away.

Association can be established. Causation, however, is far from clear. Decentralised enterprise may have made necessary a listening State. One person, one vote may have made possible a self-confident economy. The economy may have caused the polity. The superstructure may have shaped the basis. Both together, alternatively, may themselves be the dependent variables that were moulded by Calvin on individualism and Newton on observation because authority was challenged by predestination and belief undermined by experiment. What is clear is that democracy is seldom found without exchange and that exchange is usually the complement that makes democracy whole.

Choice is the intellectual link: 'Liberal-democracy is the politics of choice. Everything is up for choice, or may be up for choice at any time - everything, that is to say, except the liberal society and the democratic franchise themselves' (ibid.: 33). Exchange, like democracy, is goal-orientated and selfaware. Democracy, like exchange, acknowledges the sovereignty of the individual and the competitiveness of the entrepreneurs. In the one case as in the other, the citizen is seen as a purposive improvement-seeker who shops rationally so as not to waste scarce resources and reveals preferences that must be respected as uniquely his own.

We buy what we want with our money. 'We buy what we want with our votes' (ibid.). Democracy, like exchange, is only the procedure that tallies up the tastes. The irreducible locus of power remains the equal individuals with equal rights that are the highest court of appeal. Yet there is a difference between the two modes of command. In the political market the rule is one person, one vote: we 'treat each other in a democratic spirit, that is to say, on an equal footing' (Aristotle, 1981: 324). In the economic market the distribution of income is itself an explicandum and a disputandum: one man 'wears several men's clothes, eats several men's dinners, occupies several families' houses, and lives several men's lives' (Tawney, 1921: 39). The felt unfairness is a reason why good democrats sometimes vote to overturn effective demand. Even if it is efficient, they will say, still the market leaves equal citizens with unequal power and that does not seem right.

Individuals make choices but they do so within the framework of the two distributions. Culture imposes a further constraint. The market is a shared language where consumers buy symbols that are badges and trophies in a normative pattern. Political democracy is the common identity where citizens make choices in the light of their national loyalty. Togetherness and unity arguably play a secondary role where consumers swap apples for oranges in 
an impersonal exchange. Statehood is different. A common past and a collective future are more prominent in the choice calculus of voters for whom cooperation and cohesion mean an affectual overlap that is less frequently found in the economic market.

Ein Reich, ein Volk is not the Smithian 'higgling and bargaining' of disembodied dyadic exchange. Political choice is more than strangers assembling periodically for an election and then going their own way. It is also patriotism and conservatism, collective emotions and the consciousness of a common task. Democracy is the individual because only the individual can make a choice. Yet democracy is also groups of individuals because socialisation and role will influence the mixed portfolio that the situated individual will select.

Democracy and exchange must not be confused with growth and affluence. Yet there is a link. Lockean civil liberty is the precondition for the Smithian invisible hand that sets the dynamic loose. Both democracy and exchange owe much of their legitimacy to the fact that both are associated in the popular mind with rising living standards and mass consumption. It is doubtful if either would enjoy as much support if it were synonymous with stagnation and poverty.

Entrepreneurship produces prosperity. Prosperity is conducive to democracy. Mass production standardises the consumer culture and reinforces the consensus that one citizen is the equal of another. Material insecurity is the historic breeding ground for the intolerance of xenophobic scapegoating. Economic well-being, on the other hand, is associated with permissive accommodation and across-the-board self-determination: 'The affluence created by industrialization will undermine totalitarian regimes, for a high mass consumption society cannot support the extremist fervour and revolutionary dedication such regimes require' (Lively, 1975: 64).

A rapidly progressing economy, moreover, will produce a range of intermediate associations which multiply the concentrations of power and make the democracy more representative: 'Since industrialization depends on increasing division of labour and skills, it will add to the number of interest-groups making demands within the political system and so encourage the social pluralism in which democracy flourishes' (ibid.: 64). The sheer number of the competing coalitions makes the government more aware of the heterogeneity of opinion, more responsive to the variety of the groupings that add up to the whole. 'Polyarchy' is the term Dahl uses to describe the system of not majority rule and 'not minority rule but minorities rule' (Dahl, 1956: 132, emphasis added). The outcome is a set of policies that brings the nation closer to unanimity of consent than would the either/or of elective despotism: 'The making of governmental decisions is not a majestic march of great majorities united upon certain matters of basic policy. It is the steady appeasement of 
relatively small groups ... The numerical majority is incapable of undertaking any co-ordinated action. It is the various components of the numerical majority that have the means for action' (ibid.: 146). Growth increases the number of intermediate affiliations and embeds the power equilibrium more deeply in the civil society. In that way it makes the democracy more representative still.

Growth is change, qualitative and quantitative both. That too is a reason why industrialisation, urbanisation and electrification must in the long run weaken the power of the tyrant to force matter into a momentum that he prescribes. It is hard to be a dictator in a dynamic economy, uncertain and innovative, forever on the move. Planners cannot plan for unknowledge. At some point they will have to choose between prosperity and control.

Exchange can reinforce democracy. Democracy can reinforce exchange. While the Lockean State might wish to confine itself to the law and order that is written down in the compact, it is also the case that an extended agenda might be demanded precisely because good democracy is also good business.

Thus the citizens might demand infrastructure such as cheap public transport because the market has no incentive to supply public goods. They might request laws to contain pollution because externalities lead to illness and cost days off work. They might insist on compulsory education because skills and attitudes are essential and on-the-job training is unlikely to be enough. It would be a mistake to think that citizens who believe in exchange will fail to use democracy to make the State more influential and more involved. If a cut in corporation tax grows the economy by creating new jobs, so, some will argue, does the nationalisation of the banks, because it distributes capital in accordance with social rather than private net return.

There are, moreover, further dimensions to felt well-being besides the commercial exchanges that feed through into exponential acquisitiveness. People demand inner-city parks and subsidised theatres because fresh air and heroic verse improve the quality of life. Statutes like child labour laws and minimum wage laws are desired because they come between the vulnerable and the abusive. Income maintenance when the individual is unemployed or incapacitated or simply too old confirms to the beneficiary and the community as a whole that citizenship is not contingent on being able to contribute to economic growth.

Aristotle took the view that a minimum guarantee of human decency is an affirmation of the whole even as it is an acknowledgment of the part. In calling for public support, he emphasised that the We has an interest in harmony and social stability that is not to be confused with the stake held by the I in a square meal and a hospital bed: 'The duty of the true democrat is to see that the population is not destitute; for destitution is a cause of a corrupt democracy' (Aristotle, 1981: 375). Exclusion being a threat to the organism and not 
just to the cell, 'every effort therefore must be made to perpetuate prosperity. And since that is to the advantage of the rich as well as the poor, all that accrues from the revenues should be collected into a single fund, and distributed in block grants to those in need' (ibid.).

Aristotle did not want to see a dependency culture. He was clear that cash and kind should be treated as seed corn that would empower the left-out to rejoin their fellows. That is why the grants, not mean but generous, should be paid 'if possible in lump sums large enough for the acquisition of a small piece of land, but if not, enough to start a business, or work in agriculture' (ibid.). The community should assist the destitute into an occupation by which they can earn their living. The destitute in return should make their proper contribution to political democracy and economic exchange. They should certainly not burn the shophouses down. Welfare has its rights as well as its duties. Welfare is a We. It is not just an I.

It might, of course, all go badly wrong. Democracy and exchange can subvert the planning and strengthen the decentralisation. They can also work against one another and blunt the sensitivity of the consultation.

The exchange economy in the prediction of Schumpeter and Galbraith must achieve progress at the expense of the small and medium enterprise that is crowded out by the giants. Competition becomes regimented as oligopolists and monopolists try to eliminate surprises from their scenarios. Profit seekers are marginalised by bureaucrats and technocrats who have no strong need to put the customer first. Corporate executives play golf with prime ministers and wrest disproportionate concessions that one man, one vote cannot secure. If economic progress means a stronger attachment to democracy, it can also mean a reduction in the influence of the man in the street relative to the grandees and the plutocrats who wield disproportionate power at the top.

Just as exchange might be a threat to democracy, so democracy might undermine the legitimacy of exchange. Since the majority are less well-off than the penthouse, democracy could discredit itself by oppressing decent meritocrats merely because they have done abnormally well. Courting popularity, politicians could impose punitive rates on high incomes and spend more than they can afford on transfers. Paper money might irresponsibly be created since conspicuous kindliness buys wavering votes. An intergenerational deficit might recklessly be passed on since the unborn future cannot swing a marginal constituency that needs a dam.

Incentives to save, to work, to take risks become less. Price signals become distorted by inflation. Unemployment balloons as the out-of-work refuse the going wage. Ultimately the liberal order, seen to have lost control, is replaced by a strong man and a non-democratic State which alone can keep active enterprise on the road. 


\subsection{THEORIES OF POLITICAL ECONOMY}

This book is about explanations and models. It is about the way in which five important thinkers have sought to make sense of the two-way relationship between democracy and exchange, politics and economics. Chapters 2 to 5 deal with Joseph Schumpeter, Chapters 7 to 10 with T.H. Marshall. Chapter 6 is about J.K. Galbraith, Chapter 11 about Richard Titmuss and Chapter 12 about Adam Smith.

Chapters 2 and 3 are concerned with Joseph Schumpeter's two theories of democracy. Chapter 2, on the classical doctrine, considers the General Will and the imperative of consensus. Citing authorities like Pericles, Aristotle, Rousseau and Bosanquet, it suggests that politics is not problematic where the rulers passively rubber-stamp what the common man or woman already knows to be right. Chapter 2 shows that Schumpeter was profoundly dissatisfied with an approach that could not account for dissensus or for the tyranny of the majority. Schumpeter was particularly critical of the classicals because they ignored the constructive lead of imaginative champions who maximised the common good by delivering a product that Henry Dubb had not yet discovered that he liked.

Chapter 2 concludes by showing that Schumpeter did not support industrial democracy: he felt that the division of labour dictates that wise and thinking commanders should be allowed to get on with the job. Chapter 3 continues the discussion of leadership by arguing that Schumpeter believed democracy to be the rule, not of the people, but of the elected politician. Ill-informed, biased, easily manipulated, the masses are exposed to supplier-induced demand to such an extent that the reader half expects Schumpeter to jettison altogether any defence of voter-pleasing oligopoly. Schumpeter did not have a great deal in common with the calculative rationality of Downs. He had a great deal more in common with Pareto, Mosca and Michels, who wrote about the elite and treated the Shop of State as the den of fraud and prejudice. Yet Schumpeter remained a democrat. Good procedures produce tolerable outcomes. Even if they did not, a conviction liberal cannot convincingly speak for 'I am the State'.

Chapter 4 goes behind the voting mechanism to discover in what circumstances the system functions best. Schumpeter felt that the best democracy was one in which politicians and bureaucrats were internally motivated by a professional ethic, where the agenda was not too long to be manageable and where normative self-control provided the greater part of the checks and balances. Schumpeter was more interested in the consensual binding than he was in the codified constitution. A sociologist more than a political engineer, he shared his interest in values that circumscribed activities with his near contemporary, Max Weber. 
Chapter 5, on economic systems, situates Schumpeter's preconditions for the success of democracy in the context first of market capitalism and then of planned socialism. Schumpeter believed that democracy stood as good a chance in the directed order as it did in free enterprise. He also believed that, irrespective of economics, the State would expand its influence into social policy and the relief of distress. The same central value system that protected political democracy from one man, one vote, once also insured the poor, the unemployed, the victims of geographical mobility, the social pathologies of entrepreneurial upheaval against the contingencies of cold and hunger, exile and embarrassment. The Schumpeterian community is just, altruistic and caring. Schumpeter believed that economic progress and social progress would inevitably go hand in hand.

Chapter 6 examines the welfare capitalism of J.K. Galbraith. Galbraith is an evolutionist who believes that matter is in motion and that thought only photographs what the economic world creates. Looking to the future, Galbraith anticipates public spending on roads and schools, State subsidies to small businesses, government safety nets for corporate risk takers, the protection of beauty spots because the environment is a public good. He is absolutely confident that democracy will automatically validate the policies that have to be. Voters have no choice. They will understand that ideas are powerless before the might of events and ratify what they must.

Chapter 7, turning to T.H. Marshall, shows that this strong supporter of Britain's Labour Party redefined socialism to mean, not principled nationalisation and economic regimentation, but social integration and complementary infrastructure. It emphasises his debt to Green and Hobhouse on social policy as the full unfolding of self. It demonstrates that the stunted rejects, like the detribalised successes, could not be called proper citizens since they were deficient in the common culture which injected comradeship into what would otherwise be a paper nationhood that had no heart.

Chapter 8, continuing the theme of citizenship as belonging, builds on the canonical names of Weber, Tönnies, Durkheim and the Alfred Marshall who wanted every man to be a gentleman to show that T.H. Marshall is a part of a tradition which embeds even narrow commerce in something social beyond exchange. Marshall as a historian traces the evolution of rights in Britain from the civil rights of the eighteenth century through the political democracy of the age of Empire to the welfare services of the final stage on the road to mix. The rights strengthen one another. The power of the three makes the modern synthesis both effective and popular.

Chapter 9, about social distance and social class, asks how a stratified society can also be a unified one. Marshall, closer to Weber than to Marx, does not see the capital-labour dialectic as an unacceptable architect of inequality. Status and opportunity are more disruptive. The dynamo of growth was Davi $_{\text {Reisman }}{ }_{91845426828}$ 
already narrowing the perceived gap in self-presentation. Business was making the Englishmen more and more alike. Yet welfare was needed as well. Social policy would release blocked potential. It would also bring fellow citizens closer together through common experiences that unite.

Chapter 10 demonstrates that Marshall in his retirement years returned to his three sets of rights to model a 'hyphenated society' of political democracy, capitalist economics and the welfare support which corrected an interpersonal shortfall. It compares Marshall with Anthony Crosland to show that welfare plus affluence legitimated by democracy was not a combination which Marshall was alone in expecting and endorsing. Marshall's socialism is comprehensive schools and the National Health. It is social-ism that leaves the economy by and large to exchange. It is not Schumpeterian economics-ism that delegates the quantity and the quality to the Plan.

Chapter 11 revisits the idea of a citizenship-based Health Service as an exemplar of socialism as mutual aid, equal access and shared facilities. It explores the reasons why Richard Titmuss felt that the median citizen had an innate need to donate children, blood and money in order to ensure the survival of a multigenerational concern of which he was proud to be a part. The representative voter had a strong sense of collective responsibility. He had expressed the wish to redress the privatisation of satisfaction and to befriend the needy who could not pay. Democracy and capitalism had enjoyed a long and productive association. Titmuss was convinced that the typical democrat was increasingly insisting on the new freedom to give to his neighbours through the State.

Chapter 12 concludes the book with a discussion of Adam Smith on the greatest happiness of the greatest number. Smith wanted the invisible hand because gain-seeking enterprise alone would release the genie that would supply the wealth. Smith also wanted the visible hand because pragmatic management was essential if unguided interest rates were not to misprice scarce capital nor neglected education leave the masses vulnerable to a Savonarola and or a Jack Cade. Smith was not a democrat. An Ireton and not a Rainborough, he was, however, a believer in universal betterment, selfperceived. He expected the market and the State to work together to supply the well-being that the citizens would have demanded if they had had their statesman's superior knowledge and his ability to do what was best for all.

We today live on the middle ground. This book is about the middle ground. It does not say which insights are right and which are wrong. Different people like different dogs and that is the way it is. This book is not about scoring winners and spotting losers. It is something that in a sense is more in keeping with the tolerance both of democracy and of exchange. It is about discussion. It compares the contentions, comments on the evidence and in the end, 
concludes that the exchange of views is what prevents the democracy from slipping back to the bellum.

C.B. Macpherson has this to say about the active and the passive stance: 'It is better to travel than to arrive. Man is not a bundle of appetites seeking satisfaction but a bundle of conscious energies seeking to be exerted' (Macpherson, 1973: 5). The study of stimulating theories is always a dialogue and a process. The reader takes in what the author has to say. The reader then adds his own intellectual potential to that of the author whose ideas are the catalyst that empower him to grow. 